\title{
Organocatalytic Chemoselective Reduction of Phosphine Oxides to Phosphines
}

\section{Key words}

silanes

Brønsted acids

phosphine oxide reduction

chemoselective reduction

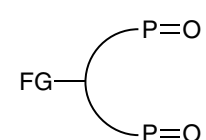

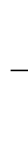
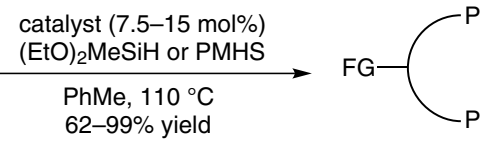

phosphine

phosphine oxide

$\mathrm{FG}=$ aldehyde, ketone, olefin, ester

$\mathrm{PMHS}=$ polymethylhydrosiloxane

\section{Proposed mechanism:}

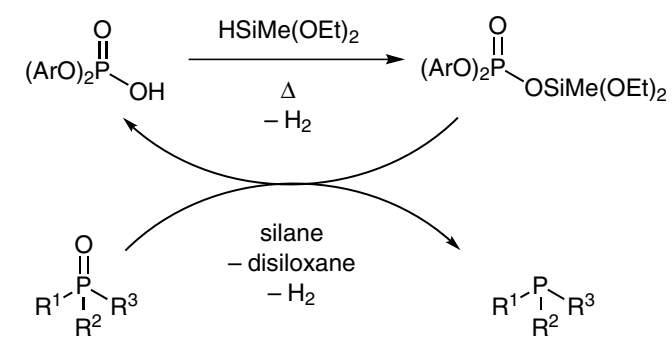

phosphine oxide

phosphine

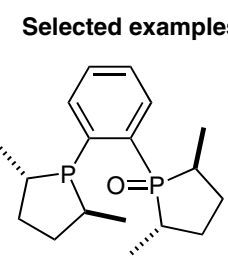

$86 \%$ yield

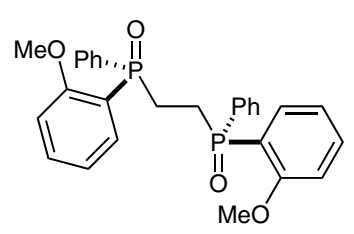

$62 \%$ yield

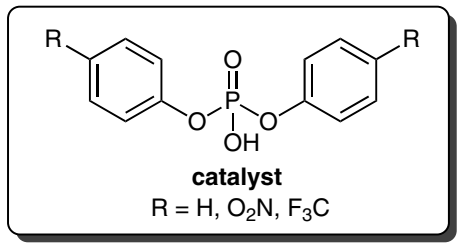

Some examples of phosphines:<smiles>Nc1ccccc1P</smiles>

$81 \%$ yield<smiles>Cc1cc(C)cc(P(c2cc(C)cc(C)c2)c2cc(C)cc(C(C)(C)C)c2)c1</smiles><smiles>Cc1cccc(P)n1</smiles>

$88 \%$ yield<smiles>COCP(c1ccccc1)c1ccccc1</smiles>

$71 \%$ yield<smiles>CP(c1ccccc1)P(c1ccccc1)C1CC1</smiles>

$92 \%$ yield $\mathrm{Cy}_{3} \mathrm{P}$

$88 \%$ yield

$\mathrm{Ad}_{2} \mathrm{HP}$

99\% yield<smiles>CS(C)(=O)=CCCOC(=O)c1ccc(P)cc1</smiles>

$73 \%$ yield<smiles>CCCCNC(=O)CP[OH+]c1ccccc1</smiles>

$86 \%$ yield<smiles>COc1ccc(-c2ccccc2)cc1C#N</smiles><smiles>CC(=O)c1ccc(P(=O)(O)c2ccccc2)cc1</smiles><smiles>O=Cc1ccccc1P(=O)(O)c1ccccc1</smiles>

$82 \%$ yield

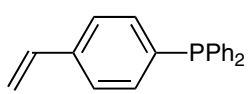

$89 \%$ yield
Significance: Organophosphines represent valuable intermediates, catalysts, and ligands for transition-metal catalysis. Here, the authors report the utilization of inexpensive silanes by Brønsted acid catalysis, which shows broad functional group tolerance towards aldehydes, ketones, olefins, nitriles, and esters. Chemoselectivities of 99:1 for $\mathrm{P}-\mathrm{O}$ double bonds and retention of the configuration at the P-center were achieved.

SYNFACTS Contributors: Benjamin List, Philip S. J. Kaib

Synfacts 2013, 9(1), 0099 Published online: 17.12.2012

Dol: 10.1055/s-0032-1317901; Reg-No.: B11412SF
Comment: The catalytic chemoselective reduction of $\mathrm{P}-\mathrm{O}$ double bonds $(502 \mathrm{~kJ} / \mathrm{mol}$ ) is a formidable challenge in synthetic chemistry. This metalfree protocol under convenient, air-insensitive, and safe reaction conditions for aryl, alkyl, monoand bidentate phosphine oxides with its high functional group tolerance indicates possible applications in catalytic Wittig, Appel, and Staudinger reactions. 